See discussions, stats, and author profiles for this publication at: https://www.researchgate.net/publication/281006452

\title{
Risk factors associated with resistance to HIV testing among transwomen in Brazil
}

Article in AIDS Care · August 2016

DOI: 10.1080/09540121.2015.1066751

CITATIONS

6

8 authors, including:

Carl Kendall

Tulane University

184 PUBLICATIONS 3,816 CITATIONS

SEE PROFILE

Raimunda Hermelinda Maia Macena

Universidade Federal do Ceará

42 PUBLICATIONS 319 CITATIONS

SEE PROFILE
READS

107

Rosa Maria Salani Mota

Universidade Federal do Ceará

172 PUBLICATIONS 2,142 CITATIONS

SEE PROFILE

-2) Florence Kerr-Correa

São Paulo State University

90 PUBLICATIONS 784 CITATIONS

SEE PROFILE

Some of the authors of this publication are also working on these related projects:

Qualitative Research View project

Project Leprosy View project 
This article was downloaded by: [Francisco Marto Leal Pinheiro J únior]

On: 15 August 2015, At: 03: 22

Publisher: Routledge

Informa Ltd Registered in England and Wales Registered Number: 1072954 Registered office: 5 Howick Place, London, SW1P 1WG

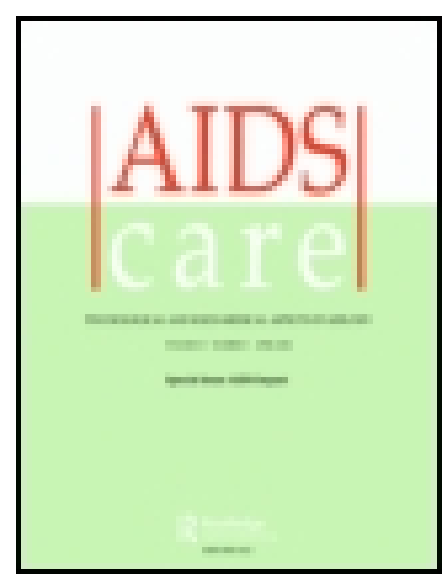

CrossMark

Click for updates

\section{AIDS Care: Psychological and Socio-medical Aspects of AIDS/HIV}

Publication details, including instructions for authors and subscription information: http:// www.tandfonline.com/loi/ caic20

\section{Risk factors associated with resistance to HIV testing among transwomen in Brazil}

\author{
F. M. L. Pinheiro J únior ${ }^{a}$, C. Kendall ${ }^{b}$, T. A. Martinss, R. M. S. Mota ${ }^{d}$, R. H. M. Macena ${ }^{a}, J$. \\ Glick $^{b}$, F. Kerr-Correa ${ }^{\mathrm{e}} \&$ L. Kerr ${ }^{\mathrm{a}}$ \\ a Department of Community Health, Federal University of Ceará, Fortaleza, Brazil \\ ${ }^{b}$ Department of Global Community Health and Behavioral Sciences, Tulane University, New \\ Orleans, LA, USA \\ c Ministry of Health of Ceará State, Fortaleza, Brazil \\ d Department of Statistics and Applied Mathematics, Federal University of Ceará, Fortaleza, \\ Brazil \\ e Department of Neurology and Psychiatry of São Paulo State University, Botucatu, Brazil \\ Published online: 14 Aug 2015.
}

To cite this article: F. M. L. Pinheiro J únior, C. Kendall, T. A. Martins, R. M. S. Mota, R. H. M. Macena, J. Glick, F. Kerr-Correa \& L. Kerr (2015): Risk factors associated with resistance to HIV testing among transwomen in Brazil, AIDS Care: Psychological and Socio-medical Aspects of AIDS/ HIV, DOI: 10.1080/ 09540121.2015.1066751

To link to this article: http:// dx. doi.org/ 10.1080/09540121.2015.1066751

\section{PLEASE SCROLL DOWN FOR ARTICLE}

Taylor \& Francis makes every effort to ensure the accuracy of all the information (the "Content") contained in the publications on our platform. However, Taylor \& Francis, our agents, and our licensors make no representations or warranties whatsoever as to the accuracy, completeness, or suitability for any purpose of the Content. Any opinions and views expressed in this publication are the opinions and views of the authors, and are not the views of or endorsed by Taylor \& Francis. The accuracy of the Content should not be relied upon and should be independently verified with primary sources of information. Taylor and Francis shall not be liable for any losses, actions, claims, proceedings, demands, costs, expenses, damages, and other liabilities whatsoever or howsoever caused arising directly or indirectly in connection with, in relation to or arising out of the use of the Content.

This article may be used for research, teaching, and private study purposes. Any substantial or systematic reproduction, redistribution, reselling, loan, sub-licensing, systematic supply, or distribution in any form to anyone is expressly forbidden. Terms \& Conditions of access and use can be found at http:// www.tandfonline.com/page/terms-and-conditions 
AIDS Care, 2015

http://dx.doi.org/10.1080/09540121.2015.1066751

\title{
Risk factors associated with resistance to HIV testing among transwomen in Brazil
}

\author{
F. M. L. Pinheiro Júnior ${ }^{\mathrm{a}}$ (D, C. Kendall ${ }^{\mathrm{b}}$, T. A. Martins ${ }^{\mathrm{c}}$, R. M. S. Mota ${ }^{\mathrm{d}}$, R. H. M. Macena ${ }^{\mathrm{a}}$, J. Glick ${ }^{\mathrm{b}}$, \\ F. Kerr-Correa ${ }^{\mathrm{e}}$ and L. Kerr ${ }^{\mathrm{a} * \dagger}$
}

${ }^{a}$ Department of Community Health, Federal University of Ceará, Fortaleza, Brazil, ${ }^{b}$ Department of Global Community Health and Behavioral Sciences, Tulane University, New Orleans, LA, USA; ${ }^{c}$ Ministry of Health of Ceará State, Fortaleza, Brazil;

${ }^{d}$ Department of Statistics and Applied Mathematics, Federal University of Ceará, Fortaleza, Brazil, ${ }^{e}$ Department of Neurology and Psychiatry of São Paulo State University, Botucatu, Brazil

(Received 23 January 2015; accepted 19 June 2015)

\begin{abstract}
Transwomen are a high-risk population for HIV/AIDS worldwide. However, many transwomen do not test for HIV. This study aimed to identify factors associated with resistance to HIV testing among transwomen in Fortaleza/CE. A cross-sectional study was conducted between August and December 2008 with a sample of 304 transwomen recruited through respondent-driven sampling. Data analysis utilized Respondent-Driven Sampling Analysis Tool and SPSS 11.0. Univariate, bivariate, and multivariate analyses examined risk factors associated with resistance to HIV testing. Less than 18 years of age $(\mathrm{OR}=4.221 ; \mathrm{CI}=2.419-7.364)$, sexual debut before 10 years of age $(\mathrm{OR}=6.760 ; \mathrm{CI}=2.996-15.256)$, using illegal drugs during sex $(\mathrm{OR}=2.384 ; \mathrm{CI}=1.310-4.339)$, experience of discrimination $(\mathrm{OR}=3.962 ; \mathrm{CI}=1.540-10.195)$ and a belief that the test results were not confidential (OR $=3.763 ; \mathrm{CI}=2.118-6.688$ ) are independently associated with resistance to testing. Intersectoral and targeted strategies aimed at encouraging the adoption of safer sexual behaviors and testing for HIV among transwomen are required.
\end{abstract}

Keywords: transwomen; HIV testing; resistance to test; HIV/AIDS; RDS; Brazil

\section{Introduction}

Transwomen are a high-risk population for HIV/AIDS worldwide (Baral et al., 2013; Herbst et al., 2008). Often, transwomen are involved in commercial sex, unprotected sex, and use alcohol and other drugs during sexual intercourse (Guadamuz et al., 2011; Martins et al., 2013; Passos \& Figueiredo, 2004; Wang et al., 2007).

Stigma, social exclusion, violence, use of hormones and injected silicone, low education and unfavorable social status are factors that increase risk for HIV in this population (Bockting, Miner, Romine, Hamilton, \& Coleman, 2013; Jeffries, Marks, Lauby, Murrill, \& Millett, 2013; Ramirez-Valles, Garcia, Campbell, Diaz, \& Heckathorn, 2008; Sanchez, Sanchez, \& Danoff, 2009). However, many transwomen do not test for HIV (Bauer, Travers, Scanlon, \& Coleman, 2012).

The marginalization of transwomen affects risk perception and motivation to access testing, leading transwomen to remain unaware of their HIV status. Despite the expansion of HIV testing and treatment, major barriers remain at the level of the patient, at health care provider and at institutional/policy (Deblonde et al., 2010). Health policies concerning transwomen are still unresolved (Cherutich, Bunnell, \& Mermin, 2013).
This study aimed to identify risk factors associated with resistance to HIV testing among transwomen in Fortaleza, Ceará State, Brazil.

\section{Methods}

\section{Procedures and sample}

A cross-sectional study was conducted between August and December 2008. The sample was selected from a list of members maintained by the only transwomanfocused NGO in Fortaleza, ATRAC (Associação de Travestis do Ceará). Sample size was estimated assuming an HIV prevalence of $10 \%$, alpha $=0.05$, and power $=0.8$. A sample of 304 self-identified transwomen living in Fortaleza, who were at least 14 years old and reported anal or oral sex in the last year, were recruited into this study. The recruitment was conducted through respondent-driven sampling (RDS), a method appropriate to use with a population that is difficult to access but connected to each other through a social network (Heckathorn, 1997; Kendall et al., 2008).

\section{Recruitment and data collection}

Respondents were recruited with the aid of Associação de Travestis do Ceará (ATRAC). To initiate recruitment

\footnotetext{
*Corresponding author. Email: ligiakerr@gmail.com

'Institution where the research was conducted. 
in this chain-link method, we selected five initial seeds representing different social classes. Each seed and study participant received three coupons to distribute to transwomen they know by name and have seen in the past 30 days. This procedure was followed until we reached sample size. Each participant that completed the questionnaire received 10 reais ( US\$5) as incentive. To incentivize recruitment, the recruiter received an additional 10 reais ( $\sim$ US\$5) per recruit.

Data collection took place at ATRAC after initial review of eligibility and signed consent procedures. The interview was conducted by a member of the project staff in a private room, using a questionnaire for men who have sex with men (MSM) proposed by UNAIDS (Monzon, 1995) that was modified after formative research.

\section{Variables}

Social class assignments used the Brazil Economic Classification Criteria (ABEP, 2008). The Alcohol Use Disorders Identification Test (AUDIT) was used to score alcohol use (Babor, Thomas, Higgins-Biddle, Saunders, \& Monteiro, 2001). Anti-transwoman discrimination was self-reported.

\section{Statistical analysis}

Data were weighted using Respondent-Driven Sampling Analysis Tool 5.6 (RDSAT) and exported to SPSS 11.0, for bivariate and multivariate analyses. Variables significant at 0.05 in bivariate analysis, or identified in the literature, were used in the logistic regression model.

\section{Ethical aspects}

The study was approved by the Research Ethics Committee of the São José Infectious Diseases Hospital, Fortaleza, Ceará, Brazil (protocol number: 01/2007).

\section{Results}

\section{Social context and HIV testing}

Respondents reported an average of 22 transwomen $($ mean $=12, \mathrm{SD}=59)$ in their social networks. The seeds produced long chains and branches (Figure 1).

Two-thirds (208) of transwomen (69\%) reported having ever tested for HIV. Of the 208, $12 \%$ selfreported as seropositive. Fifty-seven percent (174) reported testing during the past year. Most tested in public services $(77 \%)$. Reasons reported for testing: "curiosity" $(65 \%)$, feeling at risk $(18 \%)$, and ordered by a doctor $(8 \%)$.
Transwomen who are young ( $<18$ years), single, report no religious affiliation, make less than one minimum wage or more than four minimum wages, social classes D and E, have suffered discrimination, or do not believe in the confidentiality of testing, have a greater probability of having never tested (Table 1).

\section{Behavior and sexual practices, use of alcohol and other drugs, and body transformations}

Almost 70\% (145) reported sexual debut before age 14 . The age of first sexual intercourse ranged from 4 to 21 $($ mean $=12.7, \mathrm{SD}=3.069)$. Transwomen who had their first sexual intercourse before 10 years of age $(\mathrm{OR}=$ $7.945)$ or between the ages of 10 and $14(\mathrm{OR}=2.423)$ were less likely to test.

Transwomen who did not use a condom at last sexual intercourse, regardless of the type of partner, were less likely to have tested. Respondents who traded sex for money or gifts were less likely to have tested (Table 2).

Transwomen who reported risky silicone injection or the use of alcohol and other drugs during sexual intercourse were less likely to have ever tested for HIV (Table 2).

\section{Factors associated with not testing}

First sexual intercourse before age 10 increases not testing by almost seven times $(\mathrm{OR}=6.760$, Table 3$)$. Persons under 18 years are less likely to test than people over 24 years $(\mathrm{OR}=2.384)$. Illicit drug use during sex and self-report of discrimination reduce HIV testing. Not believing in the confidentiality of HIV test results reduces the likelihood of testing by almost four $(\mathrm{OR}=3.763)$.

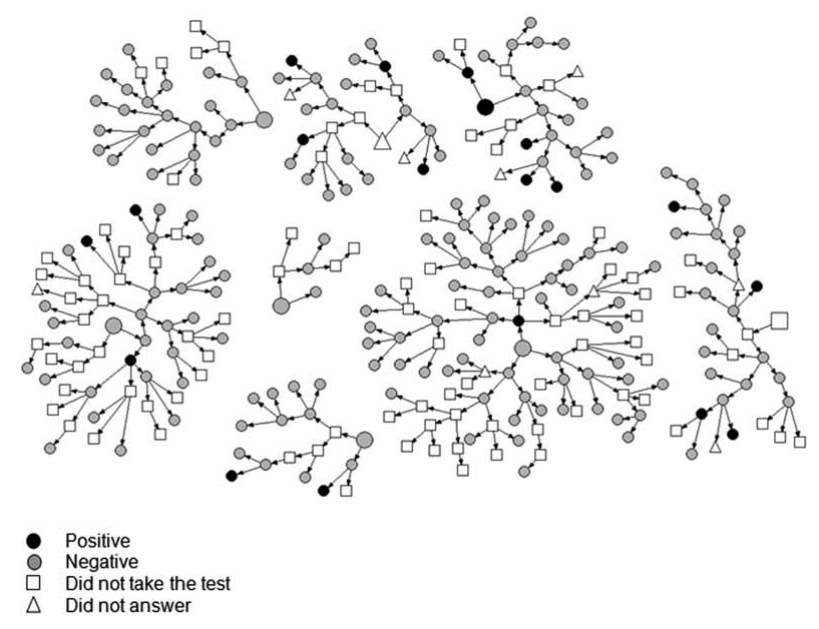

Figure 1. Network mapping of the level of interconnection of seeds considering the results that indicated HIV testing was done at least once in life. 
Table 1. Social context and health status of transwomen according to lifetime HIV testing.

\begin{tabular}{|c|c|c|c|c|c|c|}
\hline & \multicolumn{4}{|c|}{ Ever tested } & \multirow[b]{2}{*}{ OR } & \multirow[b]{2}{*}{$95 \% \mathrm{CI}$} \\
\hline & No $(\%)$ & Yes $(\%)$ & Total (\%) & $p$ & & \\
\hline \multicolumn{7}{|l|}{ Age } \\
\hline$<18$ & 49.9 & 15.5 & 25.8 & \multirow[t]{4}{*}{$<0.001$} & 6.898 & $3.035-15.677$ \\
\hline $18-28$ & 21.9 & 30.1 & 27.6 & & 1.557 & $0.664-3.647$ \\
\hline $29-39$ & 17.6 & 31.6 & 27.4 & & 1.195 & $0.497-2.871$ \\
\hline$>=40$ & 10.7 & 22.8 & 19.2 & & 1.000 & - \\
\hline \multicolumn{7}{|l|}{ Education } \\
\hline Illiterate or incomplete elementary school & 50.2 & 35.1 & 39.7 & \multirow[t]{3}{*}{0.053} & - & - \\
\hline Complete elementary school/incomplete high school & 23.6 & 34.1 & 30.9 & & - & - \\
\hline Complete high school/college & 26.2 & 30.8 & 29.4 & & - & - \\
\hline \multicolumn{7}{|l|}{ Marital status } \\
\hline Single/divorced & 98.8 & 89.0 & 92.0 & \multirow[t]{2}{*}{0.002} & 10.952 & $1.456-82.381$ \\
\hline Currently married or living together with a partner & 1.2 & 11.0 & 8.0 & & 1.000 & - \\
\hline \multicolumn{7}{|l|}{ Religion } \\
\hline Catholic & 56.9 & 71.8 & 67.3 & \multirow[t]{4}{*}{0.008} & 1.000 & - \\
\hline Protestant/evangelical & 7.4 & 9.0 & 8.6 & & 1.040 & $0.411-2.633$ \\
\hline African-Brazilian & 20.5 & 13.9 & 15.9 & & 1.869 & $0.967-3.611$ \\
\hline Atheist/no religion & 15.2 & 5.3 & 8.3 & & 3.594 & $1.542-8.376$ \\
\hline \multicolumn{7}{|l|}{ Personal income } \\
\hline$<1$ minimal wave & 47.9 & 28.3 & 34.3 & \multirow[t]{3}{*}{$<0.001$} & 3.064 & $1.743-5.385$ \\
\hline 1-4 minimal wave & 31.7 & 57.4 & 49.7 & & 1.000 & - \\
\hline$>4-$ minimal wave & 20.4 & 14.2 & 16.1 & & 2.597 & $1.279-5.273$ \\
\hline \multicolumn{7}{|l|}{ Family income } \\
\hline$<1$ minimal wave & 11.1 & 4.8 & 6.8 & \multirow[t]{3}{*}{0.056} & - & - \\
\hline 1-4 minimal wave & 77.6 & 74.0 & 75.1 & & - & - \\
\hline$>4-$ minimal wave & 11.2 & 21.1 & 18.1 & & - & - \\
\hline \multicolumn{7}{|l|}{ Social class } \\
\hline $\mathrm{D} / \mathrm{E}$ & 50.2 & 34.2 & 39.0 & \multirow[t]{3}{*}{0.012} & 3.640 & $1.417-9.353$ \\
\hline $\mathrm{C}$ & 43.3 & 49.6 & 47.7 & & 2.164 & $0.844-5.551$ \\
\hline $\mathrm{B} / \mathrm{A}$ & 6.5 & 16.2 & 13.3 & & 1.000 & - \\
\hline \multicolumn{7}{|l|}{ Living status } \\
\hline Alone & 19.6 & 25.4 & 23.7 & \multirow[t]{3}{*}{0.409} & - & - \\
\hline With partner/family & 50.1 & 50.0 & 50.1 & & - & - \\
\hline With friend/madam & 30.3 & 24.6 & 26.3 & & - & - \\
\hline \multicolumn{7}{|l|}{ Reported discrimination } \\
\hline Yes & 93.4 & 84.9 & 87.3 & \multirow[t]{2}{*}{0.050} & 2.519 & $1.014-6.252$ \\
\hline No & 6.6 & 15.1 & 12.7 & & 1.000 & - \\
\hline \multicolumn{7}{|l|}{ Believes that the HIV test results are confidential } \\
\hline Yes & 68.3 & 84.1 & 79.3 & 0.003 & 1.000 & - \\
\hline No & 31.7 & 15.9 & 20.7 & & 2.452 & $1.377-4.367$ \\
\hline Any participation in an NGO working with transwome & & & & & & \\
\hline Yes & 75.2 & 87.7 & 83.8 & 0.036 & 1.000 & - \\
\hline No & 24.8 & 12.3 & 16.2 & & 2.344 & $1.071-5.128$ \\
\hline Any participation in the public service activities & & & & & & \\
\hline Yes & 34.9 & 33.9 & 34.2 & 1.000 & - & - \\
\hline No & 65.1 & 66.1 & 65.8 & & - & - \\
\hline
\end{tabular}

\section{Discussion}

The average age of first sexual intercourse for transwomen in our study was 12 years old. In Thailand, transwomen that are sexually active before the age of 13 is 2.5 times more likely to be infected with HIV (Guadamuz et al., 2011). In our study, we found a similar risk of HIV infection for sexual debut between 10 and 14 . However, when sexual debut occurred before the age of 10, the risk of HIV infection was eightfold. The relationship between sexual abuse and subsequent sexual and drug risk, depression and PTSD is well established (Bensley, Eenwyk \& Simmons, 2000; Paolucci, Genuis \& Violato, 2001). 
Table 2. Sexual behavior, use of alcohol and drugs, and body transformations in transwomen according to their lifetime HIV test status.

\begin{tabular}{|c|c|c|c|c|c|c|}
\hline & \multicolumn{4}{|c|}{ Ever test } & \multirow[b]{2}{*}{ OR } & \multirow[b]{2}{*}{$95 \% \mathrm{CI}$} \\
\hline & No (\%) & Yes (\%) & Total $(\%)$ & $p$ & & \\
\hline \multicolumn{7}{|c|}{ Age at first intercourse } \\
\hline$<10$ & 30.4 & 9.9 & 16.1 & \multirow[t]{3}{*}{$<0.001$} & 7.945 & $3.417-7.945$ \\
\hline $10-14$ & 56.5 & 58.5 & 57.9 & & 2.423 & $1.2 .00-2.423$ \\
\hline$>14$ & 13.0 & 31.6 & 26.0 & & 1.000 & - \\
\hline \multicolumn{7}{|c|}{ Partners in the last three months } \\
\hline Stable only & 15.4 & 11.9 & 12.9 & \multirow[t]{3}{*}{0.303} & - & - \\
\hline Stable and casual & 6.8 & 11.6 & 10.1 & & - & - \\
\hline Casual only & 77.8 & 76.5 & 76.9 & & - & - \\
\hline \multicolumn{7}{|c|}{ Length of relationship with a stable partner } \\
\hline$=<12$ months & 71.7 & 51.6 & 57.2 & \multirow[t]{2}{*}{0.043} & 2.325 & $1.080-5.005$ \\
\hline$>12$ months & 28.3 & 48.4 & 42.8 & & 1.000 & - \\
\hline \multicolumn{7}{|c|}{ Have ever exchanged money, gift, or favors with sex } \\
\hline Yes & 76.6 & 86.5 & 83.5 & \multirow[t]{2}{*}{0.050} & 1.000 & - \\
\hline No & 23.4 & 13.5 & 16.5 & & 1.903 & $1.018-3.558$ \\
\hline \multicolumn{7}{|c|}{ Used a condom at sex debut } \\
\hline Yes & 37.4 & 26.1 & 29.5 & \multirow[t]{2}{*}{0.050} & 1.692 & $1.002-1.692$ \\
\hline No & 62.6 & 73.9 & 70.5 & & 1.000 & - \\
\hline \multicolumn{7}{|c|}{ Used a condom at last sex } \\
\hline Yes & 18.8 & 35.3 & 29.9 & \multirow[t]{2}{*}{0.013} & 1.000 & - \\
\hline No & 81.2 & 64.7 & 70.1 & & 2.357 & $1.208-4.599$ \\
\hline \multicolumn{7}{|c|}{ Injected liquid silicone } \\
\hline Yes & 35.9 & 55.7 & 49.8 & \multirow[t]{2}{*}{0.002} & 1.000 & - \\
\hline No & 64.1 & 44.3 & 50.2 & & 2.275 & $1.367-3.787$ \\
\hline \multicolumn{7}{|c|}{ Risk behavior for silicon } \\
\hline Yes & 31.1 & 49.5 & 44.0 & \multirow[t]{2}{*}{0.004} & 1.000 & - \\
\hline No & 68.9 & 50.5 & 56.0 & & 2.173 & $1.290-3.659$ \\
\hline \multicolumn{7}{|c|}{ Alcohol use during sex } \\
\hline Yes & 34.3 & 50.8 & 45.8 & \multirow[t]{2}{*}{0.008} & 1.000 & - \\
\hline No & 65.7 & 49.2 & 54.2 & & 2.011 & $1.206-3.355$ \\
\hline \multicolumn{7}{|c|}{ Illicit drug use during sex } \\
\hline Yes & 17.9 & 32.0 & 27.7 & \multirow[t]{2}{*}{0.011} & 1.000 & - \\
\hline No & 82.1 & 68.0 & 72.3 & & 2.212 & $1.198-4.082$ \\
\hline
\end{tabular}

Table 3. Risk factors associated with resistance of lifetime HIV testing among transwomen ${ }^{\mathrm{a}}$.

\begin{tabular}{lcc}
\hline Variables & OR $(95 \% \mathrm{CI})$ & $p$ \\
\hline 18 years old versus > 24 years old & $4.221(2.419-$ & 0.000 \\
& $7.364)$ & \\
Sexual debut 10 years old versus & $6.760(2.996-$ & 0.000 \\
>14 years old & $15.256)$ & \\
Use of illicit drugs during sexual & $2.384(1.310-$ & 0.017 \\
$\quad$ intercourse & $4.339)$ & \\
Having experienced & $3.962(1.540-$ & 0.017 \\
discrimination & $10.195)$ & \\
Do not believe in HIV test & $3.763(2.118-$ & 0.000 \\
confidentiality & $6.688)$ & \\
\hline
\end{tabular}

${ }^{\text {a }}$ The model has accuracy equal to $75.9 \%$, the sensitivity was $74.4 \%$ and specificity of $76.6 \%$.
Approximately one-third of the transwomen in our study reported never having tested for HIV. This level is lower than in an American transgender population: $14 \%$ had never been tested (Feldman, Romine, \& Bockting, 2014). Not knowing one's own positive serostatus is associated with an HIV transmission rate 3.5 times higher than those who know their positive HIV serostatus (Marks, Crepaz, \& Janssen, 2006).

Fifty-seven percent of transwomen in our sample reported testing during the previous year. While higher in transwomen than in MSM and female sex workers (FSW), levels are below global health guidelines (Chou et al., 2012; Gokengin et al., 2014).

In our study, some risk behaviors functioned as an incentive to test. Examples include: use of alcohol and illicit drugs during or before sex, and previous sex 
without condoms. But, only $18 \%$ reported perception of risk as the reason for testing. Counterbalancing perception of risk is the fear of a positive result, as suggested by Deblonde et al. (2010).

Transwomen have additional risk through prostitution, among the few occupations that transwomen can engage in (Kulick, 2013; Romano, 2008). Transwomen face discrimination in schools as well as in mainstream employment. With few employment options, they transform their bodies through silicone and hormones to begin life in prostitution (De Santis, 2009), doubling the chance of HIV infection (Guadamuz et al., 2011) and four times more risk than FSW (Operario, Soma, \& Underhill, 2008).

Transwomen discrimination also constitutes an access barrier to medical care (Avery, Hellman, \& Sudderth, 2001; Bockting, Robinson, Benner, \& Scheltema, 2004; De Santis, 2009; Kenagy, 2005; Lombardi, 2007; Melendez \& Pinto, 2009; Rachlin, Green, \& Lombardi, 2008).

When discrimination is linked to systems that should offer support, such as the police and health services, it causes transwomen to avoid seeking services, and the possibility of testing (Rhodes, Simic, Baros, \& Platt, 2008).

Given discrimination in public services, non-governmental organizations (NGOs) have a more important role in the health of transwomen. In our study, the number of transwomen participating in NGO activities was three times higher than those reporting visits to public health services. Participation in transwomen-focused NGOs empower this population and could promote testing. Unfortunately, NGOs are facing their own exclusion from HIV/AIDS programming among a series of unfortunate changes to the National AIDS Program.

\section{Conclusion}

Many factors lead transwomen to become infected with HIV, and to resist testing. It is not clear that the new Brazil national strategy of making HIV test kits widely available will be successful in this population, since even in this study, many refused to test. A strategy targeted to transwomen is needed, one that encompasses health services and NGOs who work with this population, in order to increase HIV testing. Generic solutions are not likely to be effective.

\section{Acknowledgments}

The authors thank the Transwomen Association of Ceará for supporting the research.

\section{Disclosure statement}

The authors acknowledge not to have any financial interest or benefit arising from the direct applications of their research.

\section{Funding}

This work was supported by the Brazilian Ministry of Health - Health Surveillance through the Department of STD/AIDS and Viral hepatitis (Grant no. 195/07).

\section{Conflict of Interest declaration}

No conflict of interest.

\section{ORCID}

F. M. L. Pinheiro Júnior (1) http://orcid.org/0000-00034318-552X

\section{References}

Associação Brasileira de Estudos Populacionais. (2008). Critério Brasil. Retrieved from http://www.abep.org

Avery, A. M., Hellman, R. E., \& Sudderth, L. K. (2001). Satisfaction with mental health services among sexual minorities with major mental illness. American Journal of Public Health, 91, 990-991.

Babor, T. F., Higgins-Biddle, J. C., Saunders, J. B., \& Monteiro, M. G. (2001). AUDIT-The alcohol use disorders identification test: Guidelines for use in primary care. Geneva: World Health Organization.

Baral, S. D., Poteat, T., Stromdahl, S., Wirtz, A. L., Guadamuz, T. E., \& Beyrer, C. (2013). Worldwide burden of HIV in transgender women: A systematic review and meta-analysis. The Lancet Infectious Diseases, 13, 214-222.

Bauer, G. R., Travers, R., Scanlon, K., \& Coleman, T. A. (2012). High heterogeneity of HIV-related sexual risk among transgender people in Ontario, Canada: A province-wide respondent-driven sampling survey. $B M C$ Public Health, 12, 1-12.

Bensley, L. S., Eenwyk, J., Simmons, K. W. (2000). Selfreported childhood sexual and physical abuse and adult HIV-risk behaviors and heavy drinking. American Journal of Preventive Medicine, 18, 151-158.

Bockting, W., Robinson, B., Benner, A., \& Scheltema, K. (2004). Patient Satisfaction with Transgender Health Services. Journal of Sex \& Marital Therapy, 30, 4, 277-294.

Bockting, W. O., Miner, M. H., Romine, R. E., Hamilton, A., \& Coleman, E. (2013). Stigma, mental health, and resilience in an online sample of the US transgender population. American Journal of Public Health, 103, 943-951. 
Cherutich, P., Bunnell, R., \& Mermin, J. (2013). HIV testing: Current practice and future directions. Current HIVI AIDS Reports, 10, 134-141.

Chou, R., Selph, S., Dana, T., Bougatsos, C., Zakher, B., Blazina, I., Korthuis, P. T. (2012). Screening for HIV: Systematic Review to Update the U.S. Preventive Services Task Force Recommendation. Retrieved from http://www.uspreventiveservicestaskforce.org/uspstf/ uspshivi.htm

Deblonde, J., De Koker, P., Hamers, F. F., Fontaine, J., Luchters, S., \& Temmerman, M. (2010). Barriers to HIV testing in Europe: A systematic review. The European Journal of Public Health, 20, 422-432.

De Santis, J. P. (2009). HIV infection risk factors among male-to-female transgender persons: A review of the literature. Journal of the Association of Nurses in AIDS Care, 20, 362-372.

Feldman, F., Romine, R., \& Bockting, W. (2014). HIV risk behaviors in the U.S. Transgender population: Prevalence and predictors in a large internet sample. Journal of Homosexuality, 61, 1558-1588.

Gokengin, D., Geretti, A. M., Begovac, J., Palfreeman, A., Stevanovic, M., Tarasenko, O., Radcliffe, K. (2014). 2014 European guidelines on HIV testing. International Journal of STD \& AIDS, 22, 1-10.

Guadamuz, T. E., Wimonsate, W., Varangrat, A., Phanuphak, P., Jommaroeng, R., McNicholl, J. M., ... Mock, P. A. (2011). HIV prevalence, risk behavior, hormone use and surgical history among transgender persons in Thailand. AIDS and Behavior, 15, 650-658.

Heckathorn, D. D. (1997). Respondent-driven sampling: A new approach to the study of hidden populations. Social Problems, 44, 174-199.

Herbst, J. H., Jacobs, E. D., Finlayson, T. J., McKleroy, V. S., Neumann, M. S., \& Crepaz, N. (2008). Estimating HIV prevalence and risk behaviors of transgender persons in the United States: A systematic review. AIDS and Behavior, 12, 1-17.

Jeffries, W. L., Marks, G., Lauby, J., Murrill, C. S., \& Millett, G. A. (2013). Homophobia is associated with sexual behavior that increases risk of acquiring and transmitting HIV infection among black men who have sex with men. AIDS and Behavior, 17, 1442-1453.

Kenagy, G. (2005). Transgender Health: Findings from Two Needs Assessment Studies in Philadelphia. Health and Social Work, 30(1), 19-26.

Kendall, C., Kerr, L. R. F. S., Gondim, R. C., Werneck, G. L., Macena, R. H. M., Pontes, M. K., ... McFarland, W. (2008). An empirical comparison of respondentdriven sampling, time location sampling, and snowball sampling for behavioral surveillance in men who have sex with men, Fortaleza, Brazil. AIDS and Behavior, 12, 97-104.

Kulick, D. (2013). Travesti: Prostituição, sexo, gênero e cultura no Brasil. Rio de Janeiro: Editora Fiocruz.
Lombardi, E. (2007). Substance use treatment experiences of transgender/transsexual men and women. Journal of LGBT Health Research, 3, 2, 37-47.

Marks, G., Crepaz, N., \& Janssen, R. S. (2006). Estimating sexual transmission of hiv from persons aware and unaware that they are infected with the virus in the USA. AIDS, 20, 1447-1450.

Martins, T. A., Kerr, L. R. F. S., Macena, R. H. M., Mota, R. S., Carneiro, K. L., Gondim, R. C., \& Kendall, C. (2013). Travestis, an unexplored population at risk of HIV in a large metropolis of northeast brazil: A respondent-driven sampling survey. AIDS Care, 25, 606-612.

Melendez, R., \& Pinto, R. (2009). HIV Prevention and Primary Care for Transgender Women in a Community-Based Clinic. Journal of the association of nurses in AIDS care, 20(5), 387-397.

Monzon, O. T. (1995). The Second National AIDS Research Forum. NASPCP newsletter/National AIDS/STD Prevention and Control Program. National AIDS/ STD Prevention and Control Program (Philippines), 8.

Operario, D., Soma, T., \& Underhill, K. (2008). Sex work and HIV status among transgender women: Systematic review and meta-analysis. JAIDS Journal of Acquired Immune Deficiency Syndromes, 48, 97-103.

Paolucci, E. O., Genuis, M. L., \& Violato, C. (2001). A metaanalysis of the published research on the effects of child sexual abuse. The Journal of Psychology, 135, 17-36.

Passos, A. D. C., \& Figueiredo, J. F. C. (2004). Fatores de risco para doenças sexualmente transmissíveis entre prostitutas e travestis de Ribeirão Preto (SP) Brasil. Rev. Panam. Salud Publica, 16, 95-101.

Rachlin, K., Green, J., \& Lombardi, E. (2008). Utilization of health care among female-to-male transgender individuals in the United States. Journal of Homosexuality, 54, 243-258.

Ramirez-Valles, J., Garcia, D., Campbell, R. T., Diaz, R. M., \& Heckathorn, D. D. (2008). HIV infection, sexual risk behavior, and substance use among latino gay and bisexual men and transgender persons. American Journal of Public Health, 98, 1036-1042.

Rhodes, T., Simic, M., Baros, S., \& Platt, L. (2008). Police violence and sexual risk among female and transvestite sex workers in Serbia: Qualitative study. $B M J$, 337, 1-6.

Romano, V. F. (2008). As travestis no programa saúde da família da Lapa. Saúde Soc. São Paulo, 17, 211-219.

Sanchez, N. F., Sanchez, J. P., Danoff, A. (2009). Health care utilization, barriers to care, and hormone usage among male-to-female transgender persons in New York city. American Journal of Public Health, 99, 713-719.

Wang, C., Hawes, S. E., Gaye, A., Sow, P. S., Ndoye, I., Manhart, L. E., ... Wald, A. (2007). HIV prevalence, previous HIV testing, and condom use with clients and regular partners among Senegalese commercial sex workers. Journal of Homosexuality, 83, 534-540. 